\title{
Right-Wing Populist Parties - A Pathological Normalcy? A Study of Right-Wing Populist Parties in Germany
}

\begin{abstract}
This chapter challenges the common explanation for the success or failure of right-wing populism, conducting a theory-testing analysis. Right-wing populist parties are often viewed as a temporary phenomenon, caused by some form of a crisis that weakened society. Cas Mudde offered an alternative explanation, claiming that the core sentiments of right-wing populism are rooted in society. Three concepts - authoritarianism, nativism and populism are assumed to form the basis of right-wing populism. Examining party programmes, public statements and secondary literature on the German parties Die Republikaner, Schill-Partei and Alternative für Deutschland, this chapter identifies to what extent the three notions are reflected in the parties' ideologies. Next, the chapter looks at public opinion surveys in order to detect those sentiments within the German society. The analysis reveals that the three notions are not only part of the parties' ideologies, but are also consistently present in the German public opinion. The findings furthermore indicate that the success or failure of right-wing populist parties depends on their ability to deal with organisational struggles, to broaden their agenda and to provide a charismatic leader. As a consequence, this study of right-wing populism shows that explaining the surge of such parties based on the occurrence of crisis might be a convenient argument by those who neglect that the problem goes deeper.
\end{abstract}

\section{Anne Christin Hausknecht ${ }^{1}$}

\footnotetext{
1 Anne Christin Hausknecht received a bachelor degree in European Studies at Maastricht University. She is currently enrolled for a Master in International Human Rights Law and International Criminal Law at Bangor University. Contact: annehausknecht@gmx.net
} 


\section{Introduction}

Following the first wave of right-wing populism in the 1970s, Europe has witnessed the continuous rise and fall of right-wing populist parties. Parties like the French Front National and the Austrian Freiheitliche Partei Österreichs appeared to be persistent, while other parties were short-lived. Much research has sought to explain this phenomenon, often operating in the paradigm of what Cas Mudde has called the Normal Pathology thesis, viewing crisis as the decisive factor for the fate of right-wing populist parties. Such parties are often denunciated as being the symptom of a temporarily weakened society and short-lived. According to this thesis, right-wing populist parties across Europe should have fared equally well following the economic crisis in 2008. The differing degree of their success, however, necessitates an alternative explanation, offered by Mudde's Pathological Normalcy thesis, which holds that the core features of right-wing populism are imbedded in Western societies. For Mudde, the ability to claim issue ownership decides on a party's fate. This study aims to contribute to existing academic work (Mudde 2010; Laclau 2005) by testing Mudde's thesis and offering a more analytical, instead of descriptive inspection of right-wing populism in Germany. The high level of stigmatisation of right-wing tendencies and the relatively low success of rightwing populist parties make Germany a particularly interesting case to test the Pathological Normalcy thesis.

The chapter looks at three German parties - die Republikaner (REP), the Schill-Partei, and the Alternative für Deutschland (AFD) - and attempts to explain their different levels of success between 1987 (when the REP published their first programme) until 2017.The research question asks whether the Pathological Normalcy thesis can account for the success or failure of right-wing populist parties in Germany and seeks to determine which role issue ownership and issue salience play. Right-wing tendencies in Germany are highly stigmatised due to the national-socialist past, making it a particularly insightful country to study. I claim that scholars and politicians use the Normal Pathology thesis as a simplified explanation for the rise of right-wing populist parties in Germany, denying that the core features of right-wing populism are present in the attitude of the majority. On that account, it is particularly important to reconsider the Normal Pathology thesis and observe whether there are explanations other than crisis or extreme situations that explain the success of right-wing populist parties.

The first part of the study discusses different interpretations of populism and outlines the core features of right-wing populism, followed by different interpretations of the Normal Pathology and Pathological Normalcy thesis. Next, I delineate the methodology, the analytical framework and a justification of my case selection. The analysis first investigates whether rightwing populist tendencies are rooted in the German society, and then identifies in how far the three parties classify as right-wing populist parties and what explains their success or failure. The discussion assesses in how far the Pathological Normalcy thesis can account for the developments of the three parties. The chapter closes with the conclusion that the successes and struggles of the three parties cannot be attributed to crisis, but rather that the parties' capability to claim issue ownership and address right-wing populist sentiments was a decisive factor. 


\section{Conceptual Framework}

\subsection{Populism and Right-Wing Populism}

The term populism has become a weapon widely used to denounce politicians or criticise the way newspapers report. Populism, in the words of Florian Hartleb, "functions like a chameleon, which adapts, depending on the need, the colours of its surrounding" (2004, p. 62) and is compatible with diverse ideologies (Albertazzi \& McDonnell, 2008, p. 4). Considering the lack of a clear interpretation in the existing academic work, it is necessary to clarify this notion. After delineating the main ideas on populism and right-wing populism, I turn to Mudde's threefold concept of right-wing populism, which is the foundation of the analysis.

The core feature of populism is the antagonism between the 'the pure people' and the 'corrupt elite' (Mudde 2010; Laclau 2005). Laclau detects two pre-conditions for populism, which are "an internal antagonistic frontier separating the people from power" and the articulation of shared demands "making the emergence of the people possible" (Laclau, 2005, p. 74). The people are the basis of populism, portrayed as a homogeneous and sovereign mass defined through a shared history, a common characteristic, or the membership of the lower strata in society (Pasquino, 2008). Importantly, the people primarily demarcate themselves through the opposition to a significant other. This other is typically the ruling elite, but can also be a group that is perceived as "depriving (or attempting to deprive) the sovereign people of their rights, values, prosperity, identity and voice (Albertazzi \& McDonnell, 2008, p. 4).

Combined with right-wing ideas, populism becomes an ideology that is "anti-elitist, appealing instead to the common sense of ordinary people; exclusionary, appealing to the right to cultural diversity and identity; and openly discriminatory, appealing to the right to 'national preference'"' (Betz \& Johnson, 2006, p. 311). Greven (2016) identifies that right-wing populism adds a "second antagonism of us versus them", distinguishing the pure people as a homogeneous group from those who are perceived as different (Italics added, p. 1). Core features, according to Mudde (1999) are nationalism, xenophobia, welfare chauvinism and the belief in law and order. Nationalism is the claim that the nation, as the cultural unit, and the state as the political unit, should be congruent (Mudde, 2000). Xenophobia is reflected in the exclusionary definition of the 'pure people' versus the other. Welfare chauvinism refers to the demand of economic interference of the State only to protect those that are seen as deserving. The fourth feature of right-wing populism is the belief in law and order and the conviction that the police force should be strengthened and that victims need to be protected, rather than focusing primarily on offender rehabilitation.

For Mudde (2010) right-wing populism, or the populist radical right in his words, comprises three notions. The first feature is nativism, which combines xenophobia and nationalism and holds that "states should be inhabited exclusively by members of the native group" and sees non-native aspects as a threat to the nation (Mudde, 2010, p. 1173). Nativism is the belief that nation and state should be one, and that the nation-state should be preserved to those who qualify as the 'pure people'. The second feature is authoritarianism, which can be equalized with the belief in law and order. 
Last, populism is the third notion, founded on the antagonism between the pure people and the corrupt elite and the idea that "politics should be an expression of the volonté genérale" (Mudde, 2010, p. 1175). Those three aspects - nativism, authoritarianism and populism - serve as the foundations for the analysis, which first assesses in how far those features are vested within the German society and then establishes in how far the ideologies of the three observed parties reflect these features. Acknowledging that there are different names for the observed phenomenon, I coherently refer to those parties as right-wing populist.

\subsection{Normal Pathology and Pathological Normalcy Thesis}

The Normal Pathology thesis builds on the idea of the modernization crisis, claiming that globalisation and industrialisation caused insecurities and fear, motivating people to turn towards an ideology that promises the restoration of what they perceive as lost (Decker, 2008). Decker (2013), one of the main scholars operating in this paradigm, argues that populist parties reflect the fears of the people of losing their status and are thus a product of modernization crisis. The scholar points to constitutional particularities in Germany, such as the five percent threshold for entering parliament, to account for the low level of success of right-wing populism. Deiwiks (2009) agrees that modernization has caused cleavages and stirred fear among the perceived losers of those developments, but adds that a crisis does not need to be real, but can be presumed. Recently, scholars have pointed to the refugee crisis and the financial crisis to explain the surge of right-wing populism. The electoral success of the youngest party observed, the AFD, could be attributed to the financial and refugee crisis, making it even more pressing to search for other explanations.

Mudde (2010) detected flaws in attributing the rise of populist parties solely to crisis and thus developed the Pathological Normalcy thesis, theorising that the populist right ideology is part of Western societies' attitudes. Surges of right-wing populism can mainly be attributed to the parties' ability of claiming issue ownership, by addressing concerns that none of the established parties has tackled sufficiently. Favourite topics among populist radical right parties are corruption, immigration and security. The parties claim ownership over those issues and provide simple solutions, "referring to an ideology that has been betrayed or diluted by the established parties" (Mudde, 2010, p. 1170). According to Mudde, the ideology of the populist right rests on nativism, authoritarianism and populism as a 'thin ideology'. Mudde utilizes public opinion polls published by Eurobarometer to proof that these notions are vested in Western society.

\section{Methodology}

Before immersing in the analysis, it is necessary to explain the research method and to outline the analytical framework guiding the analysis. The study follows a theory testing approach, observing three different German right-wing populist parties to examine whether the Pathological Normalcy thesis can explain their success or failure. Theories are "series of logical 
arguments that [specify] a set of relationships among concepts, constructs, or variables" (Doty \& Glick, 1994, p. 231). For Norman (2004), theories are "essential in our quest to understand and predict phenomena" and are never right or wrong, but rather a better explanation for an observed development (p. 178). Theory-testing allows the researcher to take specific predictions from a theory and use data taken from a case to test in how far these presumptions hold. I follow a concept-driven approach to theory-testing, using the three different parties to assess the "strengths, weaknesses, boundaries, and other relevant dimensions" of the Pathological Normalcy thesis (p. 67).

The analysis is divided into four parts, beginning with an observation of public opinion polls ranging from 1996 to 2016 to detect nativism, authoritarianism and populism in the common German attitude and the scrutinising how the three parties address those notions. I look at opinion polls on

i) the identification with and pride in the nation, as well as the existence of xenophobia to assess the level of nativism in Germany,

ii) the belief in law and order and opinion on public safety to detect the existence of authoritarianism, and

iii) the level of trust in established institutions and the perception of corruption in the country to recognize anti-establishment attitudes and thus evaluate to what extent populism is vested in the German society.

The second part consists of the case study, looking at the three different parties. For each of the parties, I first draw on their party programmes to identify nativist, authoritarian and populist tendencies. Facing difficulties in accessing the party programmes of the REP and the Schill-Partei, I had to choose their earliest programmes. For the analysis of the AfD, I refer to the party's latest programme, published on her website. Next, I discuss different factors that account for the party's success or failure and explore whether the experience of a (perceived) crisis might explain those developments.

One of the main prepositions of the Pathological Normalcy Thesis is that the predisposition for right-wing populism is vested within society. Observing parties that were present at different times throughout the last twenty years allows me to track in how far the notions of nativism, authoritarianism and populism exist within German society. Germany is a particularly interesting country to test the Pathological Normalcy Thesis, since no right-wing populist party has managed to establish itself for a longer time until the rise of the AfD. The national socialist past has caused a high level of stigmatisation of right-wing tendencies and "many observers thought Germany to be almost immune to successful right-wing extremism and populism" (Greven, 2016, p. 3). If the Pathological Normalcy Thesis can explain the rise of the AfD and the short-lived successes of the REP and the Schill-Party, it could be used to account for right-wing populism in other European countries as well. 
In his study on the extreme right, Mudde (2000) examined whether the REP qualifies as an extremist party, relying on the characteristics (nationalism, xenophobia, populism, belief in law and order) which he would later describe as the core values of right-wing populism. His study is limited to the classification of the REP as a party of the right in the late 1980s and in the 1990s, lacking an explanation of her development. This study contributes to Mudde's earlier work and test his latter theoretical ideas. Little academic work has been done on the Schill-Partei, a party that was present in the early 2000s, which was often not taken seriously due to the affairs of her founder Ronald Schill. Nevertheless, it is important to detect whether underlying attitudes in society can account for the party's success shortly after her foundation. The AfD, the youngest party observed, constitutes a particularly interesting case to study, since the party was created in reaction to the Euro crisis and gained more support during the refugee crisis. I claim, however, that an explanation of the party's success based on the Normal Pathology thesis would be short-sighted and that the Pathological Normalcy thesis can better account for the AFD's success.

\section{Analysis of German Right-Wing Populist Parties}

\subsection{Nativism, Authoritarianism and Populism in the German Society}

The core claim of the Pathological Normalcy thesis is that right-wing populist sentiments are not alien to Western societies. Before testing the thesis, it is necessary to detect in how far its core features are present in the attitudes of the German society. First, to identify nativist notions I look at public opinion polls that ask questions on the national pride and the level of xenophobia indicated by the position towards migrants, foreigners and asylum seekers. Second, I examine polls on the belief in law and order and the opinion on public safety to determine the existence of authoritarianism. Last, I consult the level of trust in the established institutions and the perception of corruption in Germany as indicators for anti-establishment attitudes and thus populism.

Nativism assumes that the nation and the state should coincide and that this nation-state should only be inhabited by those who deserve to be part of the society and who fulfil the attributes of the 'pure people'. This idea of the deserving and the classification of people has strong resemblance with xenophobia. ALLBUS, a survey that is conducted on a two-year basis, provides insight into xenophobia in Germany. Survey findings from 1996 and 2000 on the attitude of Germans towards foreigners indicate high levels of xenophobia, with slightly more rejection of foreigners in East Germany. In 1996, a total of 43 percent (West Germany) and 46.7 percent (East) agreed that foreigners should adapt to the German lifestyle, and almost every third of all the interviewed persons think that foreigners should be excluded from political participation. Those numbers decreased until 2000, but still every fourth German thought that foreigners should not be allowed to participate 
politically. An analysis of the Special Eurobarometer 2000 on Racism and Xenophobia reveals that in Germany "the level of acceptance of immigrants, especially of those who wish to work in the EU, is low. More respondents favour the repatriation of immigrants than other Europeans" (SORA, 2001). Another finding from the ALLBUS 1996 and 2000 was that 43 percent (1996) and 45 percent (in 2000) of Germans disagree with the statement that diversity in race, religion and culture is beneficial for a country. A study by the University Leipzig shows that xenophobia is still present in 2016. 38.5 percent (East Germany) and 30.4 percent (West Germany) of interviewees think that foreigners only come to Germany to exploit the social system and every third person would prefer the expulsion of foreigners in times of employment scarcity.

Regarding authoritarianism, a timeline created to exemplify the findings from the yearly ROLAND Legal Report indicates that the levels of trust in the police and in courts was stagnant between 1991 and 2011, with around 70 percent of people having trust in the police, and between 60 and 65 percent having trust in courts (ROLAND, 2011, p. 13). A survey conducted in 2016 shows similar results, indicating that 58 percent of Germans trust the legal justice system (European Commission, 2016a) and that the majority of Germans (79 percent) trust the police (European Commission, 2016b). Those findings indicate that people in Germany have a high level of trust in the police and see it as an important institution. Trust in the police and in the legal justice system seem to be constant and have barely changed during the examined period.

The level of trust in established institutions indicates how satisfied people are with the ruling elite and is here used to measure populism. The Hamburger Stiftung Wirtschaftsethik asked people in 2010 how much trust they had in different institutions, revealing that the federal government has been attributed low levels of trust. A similar survey conducted in 2016 shows that 54 percent had trust in the government (Survey Infratest Dimap 2016). Another indicator for the presence of populism is the perceived level of corruption, pinpointing public dissatisfaction with the existing legal system and a desire for change and more trustworthy institutions. A Special Eurobarometer on Corruption shows that the level of perceived corruption in Germany exceeds that of the EU average. In 2005, 80 percent of the interviewed thought that there was corruption in Germany at the national level, which decreased to 73 percent in 2007. In 2013, 16 percent of Germans thought that corruption was a widespread problem throughout Germany and 22 percent thought that there is corruption in the national public institutions (Eurobarometer, 2013). It is interesting to note that only six percent of the interviewed people are actually personally affected by corruption and only four percent had experienced corruption in the last year.

Decker, Kiess and Brähler (2013) looked at the changes in right-wing tendencies in Germany between 2002 and 2012. Questions on national pride and the demand that German interests should prevail were used to measure the level of chauvinism. The researchers display that the level of chauvinism was almost constant, with an average of 18.9 percent in West Germany and 17.4 percent in East Germany (Decker et al., 2013, p. 119). Similarly, the level of xenophobia proofed almost constant, with slight differences between the different age groups. Those numbers clearly support the trends in 
nativism, authoritarianism and populism retrieved in my study, which were found to be present and stable throughout the observed time.

Having detected nativism, authoritarianism and populism within the German society, I now turn towards the REP, the Schill-Partei and the AfD. For each party, I examine in how far the parties address those notions and benefited from their ability to claim issue ownership over previously disregarded themes.

\subsection{Die Republikaner}

The REP was the German response to the rise of right-wing populism that was witnessed in Europe in the 1970s. Until 1983, right-wing populism only played a role in Germany when looking "partially worried, and partially pitiful" across the border (Decker, 2002) at parties such as the French Front National, the Italian Lega Nord or the Austrian Freiheitliche Partei Österreichs. The REP was founded by a group of former CSU politicians, who were dissatisfied with the governing elite. Franz Schönhuber, a former TV host, soon became the party leader following internal struggles with the other two heads Ekkehard Voigt and Franz Handlos (Morgenstern, 2012). The party's success was confined to the years from 1989 to 1992, with electoral successes in the two Southern Bundesländer Baden-Württemberg (10.9 percent at the state-wide election) and Bavaria, as well as in Berlin ( 7.5 percent at the 1989 elections). The party won 14.6 percent of the votes at the Bavarian elections to the European Parliament in 1989 and was only 0.1percent short of entering the German Bundestag at the federal elections (all data retrieved from Morgenstern, 2012). The REP was not able to maintain her success and slowly lost voters. Schönhuber's autobiography, revealing that he had been a member of the Waffen-SS, reinforced rumours that the party was leaning towards the far right. The party still exists today, but leads a shadowy existence.

A look at the REP's first programme in 1987 reveals that nativism was a defining feature from the beginning onwards. The party demanded the creation of an educational system that promotes German values, which were seen as intrinsically linked with Christianity, German history and Occidentalism. The REP stressed the need to protect the German identity against the perceived wave of immigrants and to set strict limitations regarding the right of residence for asylum seekers. The party programme states that while "the German Republic is one of the most densely populated countries in Europe" it is not an immigration country and should "remain the country of the Germans" (REP, 1987). Foreigners were regarded as guests that exploit and damage German citizens and should have no right to social benefits, permanent residence, family reunion and other advantages (REP, 1987).

With regard to authoritarianism the party programme expresses the belief in the need to ensure law and order when stating that citizens' action should be "determined by the morals, self-discipline and tolerance, as well as the feeling of duty and responsibility for the whole" (REP, 1987). The state, on the other hand, has the constitutional duty of "ensuring all loyal citizens the base for personal freedom, public security and overall wealth" (REP, 1987, II (1)). The party's authoritarian character becomes even clearer in its most recent party programme, where the REP refers to herself as the "party for law and order" (REP, n.d., p. 22). Contrary to the clear demand for a strengthening of the national police force and strict action against (drug) 
offenders outlined in the recent programme, the party's first programme only addresses those issues indirectly. Concerning terrorism, the REP clarifies that it is the State's duty to prevent and counteract terrorist attacks and otherwise demands close cooperation between citizens and the State as a way to prevent crime (REP, 1987, p. 15).

The REP also qualifies as a right-wing populist party concerning populism. The anti-establishment attitude is indicated by the demand for a reformation of the political system towards more direct democracy. The REP claims that Germany "increasingly loses every historical, cultural and moral orientation" and that the German "mental and political culture is increasingly neglected" (REP, 1987). Since the party programme predated German reunification, one of the core demands and criticism of the REP is the "fragmentation of Germany" and the need for "state and national unity of Germany through the right of self-determination" (REP, 1987, II). Concerning the economy, the REP is inspired by welfare chauvinist ideas and demand minimal state intervention and benefits that are preserved to German citizens.

With their focus on immigration and the slogan Deutschland den Deutschen (Germany for Germans), the REP appealed to xenophobic attitudes that prevailed in the late 1980s (Funke, 1989). A survey by the newspaper Stern, for instance, found that almost a third of Germans shared xenophobic and anti-Semitic attitudes (Funke, 1989, p. 10). The REP was the first party to address those feelings and was furthermore the first party to demand a decriminalisation of the German Nazi-past (REP, 1987). The party, led by the former Waffen-SS member Schönhuber, criticised the way the German past was dealt with, thus being able to "drum up ressentiments associated with confronting the (Nazi) past" (Deiwiks 2009).

The idea of issue ownership can account for the early success and the later decline of the REP. The party attracted new voters, asking for German reunification and action against the "illegal, unnatural and violent fragmentation of the German people" (REP, 1987). When Germany was reunified and the German Government passed a reform in 1993 to restrict the right to asylum, the REP lost ownership over her core issues (Art, 2011). The REP benefited from claiming ownership over the problem of housing scarcity, at least in Berlin, where the party was the first one to address this problem (Funke, 1989). Internal struggles and a chasm between the moderate and the extreme faction caused the party to be "in complete disarray" only shortly after their success in Berlin (Art, 2011, p. 201). Former party leader Schönhuber expressed dissatisfaction with some of his leading party members when exclaiming that "he wouldn't even eat together" with them (Art, 2011, p. 200). Those internal struggles and the loss of some of their core demands weakened the party.

\subsection{Die Partei Rechtsstaatlicher Offensive- The Schill-Partei}

The Partei Rechtsstaatlicher Offensive was the most short-lived and least successful of the three observed parties. The party was founded in 2000 by the former judge Ronald Schill and became referred to as Schill-Partei. The initial name - Party for a Rule of Law Offensive - already indicates that the party was a single-issue party. Founded as a party that intended to 
counteract the (alleged) rise of crime and strengthen internal security, the Schill-Partei was able to win an astounding 19.4 percent at the elections in Hamburg in 2001 (Schmitz, 2002). A further success was experienced at the Landtagswahl in Lower-Saxony, where the party obtained 4.5 percent and was thus 0.5 percent short of entering the Landtag.

The nativist side of the Schill party was revealed primarily in connection with demands for more safety and a perceived increase in crime, particularly by foreigners. The party demanded the expulsion of foreigners who were convicted to imprisonment of a year or more, those involved in drug dealing and those who are permanently dependent on social benefits (Partei Rechtsstaatlicher Offensive Düsseldorf, 2003, p. 38). The party proposed the introduction of compulsory health checks for immigrants, testing them on infection diseases and detaining or expelling them when found with aids, hepatitis or tuberculosis (Hartleb, 2004, p. 209). Furthermore, the 2003 party programme for Düsseldorf reveals that the party clearly distinguished between German and non-native citizens, demanding that Germans and foreigners should live under the guidance of the German people instead of coexisting in a multicultural setting (Partei Rechtsstaatlicher Offensive, Düsseldorf, 2003). Party members fed stereotypes and stoked fears when referring to overflowing crime by foreigners and claiming that it was common in specific ethnic groups to always carry a weapon (Wissenschaftliche Dienste, 2011, p. 12).

Tellingly, the original name of the party - Party for a Rule of Law Offensive - indicates that authoritarianism is the core of the party. As a former federal judge, Schill created the party to strengthen the weak police and judicial system and to act against the rise of crime. Facing comparatively high crime rates in Hamburg (3969 reported incidences compared to 234 in Munich in $2000^{2}$ ), the promise to decrease crime rates was welcomed by the voters in Hamburg. The party was formed as a single-issue party with a sole focus on internal security and justice. Only slowly did the party adopt a broader agenda and began to address other issues, yet this move was unsuccessful as shown by the lack of success in later elections.

Statements by the party leader Schill such as "We are the credible alternative to the incrusted old parties, which do not recognize the interests of the people" (Schill in Hartleb, 2004, p. 179) clearly indicate an antiestablishment attitude. The party pointed to specific problems, for instance the rising crime levels and increasing poverty, and blamed the ruling parties. Contrary to the political establishment, the Schill-Partei described itself as the saviour and as a party without corrupt and incapable politicians (Schill Aktuell, n.d., p. 4). The party leader himself exclaimed that for him, being called a populist was not an insult, but rather a sign that he was popular (Hartleb, 2004). When referring to the established parties, the Schill party members use the term Altparteien (old parties), indicating that they view them as outdated. Those Altparteien are blamed for having made Germany the European problem child, being responsible for a perceived loss of wealth, and being corrupt (Hartleb, 2004, p. 182).

The Schill party's success is mostly limited to the winning of 19.4 percent at the elections in Hamburg. This surprising result can be explained by the favourable conditions resulting from Hamburg being a city-state. New

2 Data drawn from Hartleb, 2004, p. 205 
parties can address city-specific problems and have an easier time gaining attention. This can also explain the latter success in Bremen, another German city-state which was convenient for the party being geographically close to Hamburg and thus sharing similar problems. The party managed to polarize society thanks to its founder Ronald Schill, who was viewed as the most popular and simultaneously most hated politician in Hamburg and was often referred to as "Judge Merciless", owing to strict judgements in his time as a judge. The general reference to the party as the Schill-Partei reveals that Schill and the party were inseparably intertwined (Wissenschaftliche Dienste, 2011). With her focus on crime, the party brought an issue on the agenda that had not been addressed by the governing parties, although the rising crime rates had been dealt with already in the city elections 1997 (Decker, 2002).

The party did not manage to uphold those early successes. This can mostly be attributed to internal struggles and the sole focus on security and crime. The Party for a Rule of Law Offensive never managed to expand her agenda and overcome the existence as a single-issue party (Schmitz, 2002). Ronald Schill repeatedly criticised the lack of ambition and low participation rates at party sessions (Hartleb, 2004, p. 177). Moreover, an interview with newly elected party leaders in 2001 reveals that many of them were amateurs and new to the political world (Von Hollander, 2001). While the Schill-party expanded throughout Germany, it did not establish a central organisational core and thus failed to keep her members. When Schill himself was excluded from the party in 2003 following a series of public provocations and affairs, the party lost one of the core factors that had held it together (Decker, 2013, p. 382). Decker and Hartleb (2007) hold that "the rise and fall of the Law and Order Offensive (PRO) are intimately linked with the persona of its founder" (p. 440). The early success of the Schill-Partei can be explained by the strong focus on law and order issues, addressing underlying fears in society and claiming ownership over a new issue. The party's inability to expand her agenda meant that voters turned away to other parties.

\subsection{Die Alternative für Deutschland}

The Alternative für Deutschland (AfD) is Germany's youngest right-wing populist party. The party evolved from a plenum of economists, which was initiated by Bernd Lucke in 2010. The plenum was a reaction to Chancellor Angela Merkel breaching her promise to not agree with the bailout programme for Greece. The party was officially founded in February 2013 and nearly gained seats in the German Parliament at the federal election in that year. In 2014, the AfD entered the European Parliament and won seats in ten federal parliaments (Knelangen, 2017).

In her 2016 party programme, the AfD declares that she is "open towards the world, but want to be and remain Germans" (AfD, 2016, p. 6), resolving any doubt on the party's nativist perspective. The party clearly defines Germans based on their Occidental Christian culture, declaring that they tolerate other people, but do not see them as part of the German people (AfD, 2016). Germany, according to the AfD, is one of the greatest European cultural nations, which needs to be protected against multiculturalism (AfD, 2016 , p. 47). This should be ensured by reducing mass integration and instead motivating a higher German birth-rate (AfD, 2016, p. 41). Immigration is seen as eroding the German culture and causing educational 
levels to sink (AfD, 2016, p. 42). The party takes a particularly strict stance against Muslims, stating that the Sharia is incompatible with the German constitution and that Islam does not belong to Germany (AfD, 2016, p. 49).

The chapter on internal justice and security uncovers similarities concerning the rhetoric and demands on law and order between the AfD and the Schill-Partei. Like the latter, the AfD creates a crisis of internal security by claiming that "internal security in Germany is decreasing more and more" (AfD, 2016, p. 24). Strengthening the police and improving the justice system, for instance by taking strict action against youth crime, are desired to counteract the perceived rise in crime. Provocatively, the party requests the setting-up of fences and border control at the border to Austria (AfD, 2016, p. 27).

The party name was chosen in an opposition to the common phrase alternativlos (lack of alternatives) coined by Chancellor Merkel especially in the context of the economic crisis and is an indicator for the antiestablishment sentiment. Having been founded by a group of economy professors and economists, the party saw herself from the beginning on as a new alternative to the Altparteien and the leaders use the term Berufspolitiker (professional politician) to denounce the established politicians. In her party program, the AfD states that she cannot remain inactive facing the increasing "breach of law and order, the destruction of the constitutional state and the irresponsible political action against economic rationality" (AfD, 2016, p. 6). The perceived antagonism between the people and the elite becomes clear when the party states that "we are free citizens of our country. We are convinced democrats" (AfD, 2016, p. 6) in contrast to the political class. To counteract the irrational political behaviour, the AfD wants to limit the power of the established parties, decrease party financing and limit the period of office for politicians (p. 11). Besides creating an antagonism between the people (das Deutsche Volk) and the political elite (in particular the Berufspolitiker), the AfD also clarifies a clear demarcation from the European Union. The party wants a Europe of sovereign and independent nation-states and not a United States of Europe and demands a referendum on the abolition of the Euro. The AfD's focus has shifted away from the Euro-crisis and turned towards immigration issues, following the recent refugee crisis.

The high number of votes won at the Bundestag elections in 2013 came as a surprise. Schmitt-Beck explains that no small party before managed to win so many votes shortly after her foundation (2017). A look at the most recent elections in the Saarland and Schleswig-Holstein with a voter share of 6.2 percent and 5.9 percent shows that the success of the AfD was not confined to those federal elections (Statista, 2017). Schmitt-Beck (2017) examined AfD voters' motives and identified two major groups of voters: those who were early supporters and convinced by the party's critical stance on the EU, and "a majority of 'late supporters' that [...] were moved more by expressive motives, most notably xenophobic sentiments like those identified in other European countries" (Schmitt-Beck, 2017, p. 124). The author's finding that the latter, bigger group exhibits characteristics such as xenophobia and an anti-immigration attitude, supports the Pathological Normalcy thesis. The AfD thus allowed German voters to express sentiments and expectations that no other party had dared to express so far due to the stigmatisation of right-wing tendencies in Germany. 
Another explanation for the party's success is that they addressed an issue that had been neglected by the established parties. The financial crisis thus opened a window of opportunity for the group of Euro-critical economists, who demanded the abolition of the Eurozone and the conclusion of "smaller, more homogeneous monetary associations" (Schmitt-Beck, 2017, p. 126). The AfD lived up to her name and provided voters with an alternative to the established parties whose programmes had evolved around the status quo (Bebnowski, 2015). The special feature of this new party is that it supports the idea of European integration as such, but demands the preservation of national competences (Grimm, 2015). The fact that the party mainly consists of economists distinguishes her from the established parties, which are described as incompetent and striving for power.

Just like her predecessors, the AfD experiences internal

fragmentation into various fractions, comprising "conservatives, liberals, right-leaning Christian Democrats and perhaps even Christian

fundamentalists" (Arzheimer, 2015). Disputes over the party leadership led to the replacement of Lucke in 2015 by Frauke Petry. Greven (2016) detects that this change was accompanied by a new direction marked by a "language of anti-establishment, anti-Islam, anti-media and anti-immigration" (p. 3).

An aspect that distinguishes the AfD from earlier right-wing populist parties and might justify her success is that the party rhetoric is marked by the use of codes. Those keys allow the party to address rather moderate voters, as well as those leaning towards the far right. An example is the demand for an increased valuation and focus on the family, a recurring theme in the party programme. Combined with the word nation, this request for a move towards a more traditional family image stands at the same time for nationalistic ideas of who deserves to be part of this nation and who should be excluded (Bebnowski, 2015, p. 16). The AfD is thus able to win votes from the centre and the far-right, without risking being denunciated as a radical right-wing party. The future will show whether the AfD continues to be successful or whether she will experience the same fate as her predecessors. The party won 7.4 percent of votes at the recent state election in NorthRhine-Westphalia, outdoing the established Green and Left Party (Bundestagswahl, 2017).

\section{Discussion}

The above analysis reveals several similarities and differences between the parties. All the parties experienced some form of unexpected success: The REP was the first right-wing populist party with electoral successes in Germany and proofed that this was possible despite the heavy stigmatisation of the right. The Schill-Partei achieved 19.4 percent at the Land parliament election only shortly after her creation. Finally, the AfD won 4.7 percent in the elections 2013 and thus almost obtained seats in the German Parliament and has since maintained that level of success around Germany.

The analysis of public opinion surveys reveals that all three features of right-wing populism are vested in the German society. Xenophobia has proofed to be especially high and persistent, with a third of the German population showing a xenophobic attitude. All three parties address this 
sentiment by demanding stricter asylum policies and supporting the fear that foreigners deprive German citizens of employment, housing and their safety. The parties satisfy the authoritarian character, which was here measured in the belief in law and order and the opinion on public safety, by demanding increased spending on police forces, a forceful criminal justice system and particularly strict action in the case of crime by foreigners. Last, resentment and dissatisfaction with the political world and established parties motivated people to support the three parties, which clearly positioned themselves as anti-establishment parties and as an alternative to the political world.

The findings on the three parties show that the (non-) existence of a crisis cannot account for the success or failure of right-wing populist parties in Germany. The comparison of party programmes shows that the parties won voters when addressing issues that the established parties had ignored so far. The REP succeeded in Berlin by claiming to tackle the housing problems, the Schill-Partei convinced her voters of the need to strengthen internal security and increase the police force, while the AFD can be said to have won some votes by bringing the reform of the education system on the agenda. The analysis shows that issue ownership played an important role for all the three parties. Their ability to claim ownership over affairs that had been disregarded so far and provide a simple solution, enabled the parties to win voters. This finding accords with Mudde's belief that issue ownership is a relevant factor and shows that right-wing populist parties appeal to attitudes rooted in society when moving certain issues to the political agenda.

A common element in all three parties concerns internal conflict, mostly caused by the fact that some members tended towards the extreme right and the parties themselves had to fear being equated with the far-right. Such an accusation of being far-right would lead to the alienation of the rather moderately thinking parts of society. David Art (2011) has developed an explanation for why parties can still be successful despite this problem. The author holds that a party requires a certain number of moderates - "that is, nationalists who credibly subscribe to the rules of liberal democracy and steer clear of biological racism and neo-Nazism" (Arzheimer, 2015, p. 539). This enables the parties to prevent being put on an equal footing with the radical right (Art, 2011). In the case of the REP and the Schill-Partei, the number of radicals was too high, leading to the fragmentation of the parties into different right-wing movements. The AfD, so far, managed to have members with different ideological backgrounds and beliefs and could move away from radical right tendencies.

One point that might be used as an argument against the Pathological Normalcy thesis is that the AfD experienced their first successes in times of crisis (financial and refugee crisis). While the analysis found that those crises were not the main reason for voters to support the AfD, Decker and Hartleb (2007) detect that there might be some other form of crisis accounting for the success. The authors claim that there is a "deep-seated crisis of confidence, a lack of faith in the ability of democratic politics to truly represent the people" (p. 442). Right-wing populist parties, with their inherent anti-establishment attitude, can provide a solution for this crisis of confidence. The question arises how the Normal Pathology thesis defines a crisis and whether such a crisis of confidence would count as such. Considering that such a lack of confidence in the ability of the established parties to represent their citizens is subject to long-term developments and cannot be specified to one moment, 
the idea of a Zeitgeist, coined by Mudde (2004) seems more suitable than viewing it as a crisis. This Zeitgeist, or spirit of a time, is regarded as a timespecific disposition, representing a particular attitude (Bebnowski, 2015, p. 33). Bebnowski explains that this Zeitgeist usually occurs at times of economic regression, in which people generally feel dissatisfied with the established parties and are attracted by those who claim to be different. Important is that the Zeitgeist is a development over time and not the reaction to one specific event.

While this study has shown that the Normal Pathology thesis and its focus on the need of a crisis cannot explain the developments of right-wing populist parties in Germany, it remains to explain why right-wing populism in general has been unsuccessful compared to other European countries. One factor are the constitutional precautions that were taken to prevent a repeated rise of the far right. Such a provision was the Decree Against Radicals, signed in 1972, which prohibited the recruitment of people from the radical right (Art, 2011). Decker (2002) points to institutional factors, mainly the five-percent threshold that parties need to meet to enter Parliament, historical factors - the national socialist past and the stigmatisation of the right as a consequence thereof -, the lack of charismatic leaders and political opportunity structures (i.e. the ability of parties to claim issue ownership). While this chapter has addressed two of those factors - the relevance of issue ownership and the presence of a charismatic leader-further research is required concerning the importance of the societal and political aspects.

\section{Conclusion}

This study has tested the strength and weaknesses of the Pathological Normalcy thesis in explaining the development of three German right-wing populist parties. This chapter is an alternative approach to the commonly employed Normal Pathology thesis, which views right-wing populist parties as the product of exceptional circumstances. The analytical part of this study referred to Mudde's interpretation of the radical right as comprising nativism, authoritarianism and populism. To test whether those notions are actually rooted in the German society, as predicted by the Pathological Normalcy thesis, I consulted public opinion surveys on xenophobia, the belief in law and order, and on the level of trust in established institutions. The findings reveal that all three attitudes were present to a high extent in the period of investigation from 1996 to 2017. All three parties, likewise, could be classified as right-wing populist parties based on statements and demands in their party programmes that reflected nativist, authoritarian and populist standpoints. According to the Pathological Normalcy thesis, the success of a party would then be determined by her ability to claim ownership over political issues that were priorly neglected. The analysis showed that the REP benefited from addressing the issue of immigration and German reunification, hitting a nerve in the population that was dissatisfied with their current government. The REP's fast decline, after Germany had actually been reunified, demonstrates the importance of the question of issue ownership. In the early 2000s, the Schill-Partei experienced a huge electoral success in Hamburg, focusing on the (perceived) increase of crime and promising to strengthen the police and 
criminal justice system. The party founded by former judge Ronald Schill benefited from advantages of city-state elections, enabling the party to address city-specific problems. The party's inability to expand her agenda led to her decline. The AfD was identified as a particularly interesting case to test the Pathological Normalcy thesis due to her foundation and rise in the context of the economic and refugee crisis. This study showed that those crises cannot explain the party's success, but rather her ability of offering an alternative to a political elite that promoted increased European integration. Building on research on the electorates' reasons to vote for the AfD, I was able to demonstrate that an even bigger group of last-minute supporters opted for the AfD driven by xenophobic motivations. The Pathological Normalcy thesis thus holds for all three parties.

In the beginning, I claimed that politicians and scholars use the Normal Pathology thesis as an easy explanation for the success of right-wing populism. Rather than admitting that right-wing populist sentiments are rooted in society, those operating in the Normal Pathology paradigm point to the occurrence of a crisis as the single explanation for rising right-wing populism. If crisis is the decisive cause, then political actors lose all the responsibility and cannot be blamed for not addressing the underlying rightwing sentiments within society. Defining right-wing populism as a case of unpredictable illness thus allows the responsible actors to present themselves as incapable to prevent such phenomena. The Normal Pathology thesis would explain the quick decline of the REP and the Schill-Partei by claiming that the German society recovered from this temporary illness. The analysis of the parties, however, illustrates that organisational problems, internal struggles and the fragmentation into different ideological directions account for the demise of the REP and the Schill-Partei. Those problems also affect the AfD, which experienced several changes in her lead and conflict between the different internal groups.

This study found that the Pathological Normalcy thesis can explain the fate of all three observed parties. The analysis discovered that internal struggles, organisational problems, lack of a charismatic leader and constitutional particularities are factors determining a party's fate, beside their ability to claim issue ownership. Further studies operating in the paradigm of the Pathological Normalcy thesis should consider those factors and test what can account for the longevity of some European right-wing populist parties, for instance the French FN or the Austrian FPÖ. It remains to be seen whether the AfD can maintain the level of electoral support. Contrary to the REP and the Schill-Partei, the AfD has been present and successful for almost three years now. While externally, the party seems to fare well and received many votes in the recent regional elections, internal struggles and fragmentation began to weaken the young party from her core. Considering the emerging trend of closer European cooperation and positioning against the US under President Donald Trump, I predict that the established parties in Germany will receive greater support, since they began to take more proactive action and be more critical. The AfD with her anti-immigration and anti-EU position will lose issue ownership and will not be regarded as an innovative alternative any more. 